\title{
The inducible isoform of CREM (inducible cAMP early repressor, ICER) is a repressor of CYP19 rat ovarian promoter
}

\author{
V Morales, I Gonzalez-Robayna, I Hernandez, J Quintana, \\ P Santana, C M Ruiz de Galarreta and L F Fanjul
}

Departamento de Bioquímica, Biología Molecular y Fisiología, Facultad de Medicina, Universidad de Las Palmas de Gran Canaria, Las Palmas 35016, Spain

(Requests for offprints should be addressed to L F Fanjul; Email: Ifanjul@dbbf.ulpgc.es)

\begin{abstract}
The synthesis of estradiol by the granulosa cells is a prominent event in ovarian physiology and depends on the expression of $\mathrm{P} 450_{\mathrm{AROM}}$. FSH induces the expression of $\mathrm{P} 450_{\text {AROM }}$ in granulosa cells as a result of the presence in the ovarian promoter of a CRE (cAMP response element)like sequence (CLS). In rodents, LH downregulates aromatase expression during luteinization by an as yet undescribed mechanism. In granulosa cells, LH increases the expression of the inducible cAMP early repressor (ICER), an isoform of CREM (cAMP-responsive element modulator) that represses cAMP-induced transcription. The possibility that ICER represses the activity of the aromatase ovarian promoter, thus being part of the mechanism underlying the effects of $\mathrm{LH}$ was investigated. We have found that: (1) nuclear proteins from forskolinstimulated granulosa cells were specifically bound to an oligonucleotide containing the CLS sequence of the CYP19 ovarian promoter and one out of the two proteinDNA complexes formed was supershifted by an anti-
\end{abstract}

CREM antibody; (2) in granulosa cells, forskolin-induced increases in $\mathrm{P}^{4} 50_{\mathrm{AROM}}$ promoter luciferase reporter gene activity were prevented by the transient overexpression of ICER; (3) similar results were obtained in 8-Br-cAMPstimulated R2C cells, a Leydig tumor cell line routinely used for the study of $\mathrm{P} 450_{\mathrm{AROM}}$ promoter activity; (4) both ICER mRNA levels and P450 AROM promoterdriven luciferase activity were elevated 6 and $12 \mathrm{~h}$ after stimulation of $\mathrm{R} 2 \mathrm{C}$ cells with 8-Br-cAMP and were decreased 24 and $48 \mathrm{~h}$ later; (5) in an R2C polyclonal line overexpressing ICER, the promoter activity at early stages of stimulation was completely attenuated, while 24 and $48 \mathrm{~h}$ downregulation was prevented in another R2C line stably transfected with an antisense ICER construct. These results suggest that ICER represses CYP19 ovarian promoter and that LH-induced expression of ICER may serve to downregulate $\mathrm{P} 450_{\mathrm{AROM}}$ transcription in granulosa cells during luteinization.

Journal of Endocrinology (2003) 179, 417-425

\section{Introduction}

Aromatase cytochrome $\mathrm{P} 450\left(\mathrm{P}^{4} 50_{\mathrm{AROM}}\right)$ is the ratelimiting enzyme required for the conversion of androstenedione and testosterone into 17 $\beta$-estradiol (Kellis \& Vickery 1987, Simpson et al. 1994). In the female gonad the expression of $\mathrm{P} 450_{\mathrm{AROM}}$ constitutes one of the hallmarks of granulosa cell differentiation, because the production of large amounts of estradiol determines the outcome of follicular development (McNatty et al. 1979, Hsueh et al. 1984).

P450 AROM is the product of the CYP19 gene, a member of the P450 superfamily of genes which contains over 300 members in some 36 gene families (Nelson et al. 1993). P $450_{\text {AROM }}$ expression can be detected in several tissues including human placenta, brain, adipose tissue and the gonads (Simpson et al. 1997b). The coding region of CYP19, and hence the protein, is identical for every tissue where the enzyme is expressed. However the $5^{\prime}$ end of the transcripts changes and the use of alternative tissue-specific promoters allows differential regulation in each tissue (Means et al. 1991, Simpson et al. 1997a). Thus folliclestimulating hormone (FSH) activates CYP19 expression in the ovary because a CRE-like sequence bestows cAMP-dependent inductibility on the ovarian promoter (Fitzpatrick \& Richards 1994, Michael et al. 1997).

The CRE 8 bp palindromic consensus sequence binds homodimers of serine 133-phosphorylated CREB (Gonzalez et al. 1989, Dwarki et al. 1990, Yun et al. 1990, Shaywitz \& Greenberg 1999) or CREB heterodimers with ATF-1 (activating transcription factor 1) or CREM (cAMP-responsive element modulator), two other bZIP factors that share with CREB a high degree of identity within the bZIP region (Hai et al. 1989, Foulkes et al. 1991).

CREM gene is composed of several exons and encodes a set of proteins generated by alternative splicing that 
function as activators or repressors of cAMP-induced transcription (Foulkes et al. 1991, 1992, Laoide et al. 1993). An alternative intronic promoter in the CREM gene directs the rapid, cAMP-dependent transcription of a repressor isoform, therefore named inducible cAMP early repressor (ICER) (Molina et al. 1993). Alternative RNA processing of the CREM binding and dimerization domain (DBD) and $\gamma$ exon leads to the generation of four types of ICER transcripts: ICER-I and ICER-II (composed of exon $\gamma$ plus DBD-I or DBD-II), and the $\gamma$ exon-deficient isoforms: ICER-I $\gamma$ and ICER-II $\gamma$. The four proteins of the ICER family are the smallest CREbinding nuclear factors described to date. They act as repressors of cAMP-induced transcription, because while sharing with other CREM isoforms the DNA binding and dimerization domains, they are devoid of the kinaseinducible and transactivation domains. This unique feature endows ICER with a key role as a repressor that mediates the attenuation of cAMP-dependent transcription.

Upon binding to their membrane-bound G-proteincoupled receptor (Tsai-Morris et al. 1991, Heckert et al. 1992) both FSH and luteinizing hormone/human chorionic gonadotropin (LH/hCG) induce CREB phosphorylation in rat ovarian granulosa cells (Mukherjee et al. 1996). However, while FSH induces aromatase expression, LH promotes the enzyme downregulation during the luteinization process (Hickey et al. 1990, Fitzpatrick et al. 1997) by mechanisms that remain unknown. In granulosa cells, ICER expression in response to $\mathrm{LH} / \mathrm{hCG}$ has been proposed to mediate the suppression of $\alpha$-inhibin subunit gene that occurs during the preovulatory surge of LH (Mukherjee et al. 1996). Similar to $\mathrm{P}^{4} 50_{\mathrm{AROM}}$ the expression of inhibin $\alpha$-subunit in the ovary is induced by FSH through a cAMP-dependent mechanism and is downregulated by LH after ovulation (Turner et al. 1989, Pei et al. 1991). Here, we have investigated whether ICER may also attenuate CYP19 transcription, thus being part of the mechanism underlying the effects of $\mathrm{LH}$.

To test this hypothesis, we have first measured the effects of transient overexpression of ICER on the activity of $\mathrm{P} 40_{\mathrm{AROM}}$ promoter-luciferase reporter in granulosa and $\mathrm{R} 2 \mathrm{C}$ cells, a rat Leydig tumor cell line routinely used for the study of the aromatase promoter, and thereafter we have measured the activity of the promoter in R2C cells stably transfected with ICER sense and antisense constructs.

\section{Materials and Methods}

\section{Reagents and hormones}

All culture media were from Invitrogen Co. (San Diego, CA, USA). Diethylstilbestrol (DES), forskolin, 8-BrcAMP, protease and phosphatase inhibitors and all other reagents were from Sigma Co. (Madrid, Spain). Anti-
CREM and anti-CREB antibodies were from Santa Cruz Biotechnology, Inc. (Santa Cruz, CA, USA) and UBI (Lake Placid, NY, USA). Poly [dI-C] and T4 polynucleotide kinase were from Amersham Pharmacia Biotech AB (Uppsala, Sweden). AMV reverse transcriptase (M519), RNAsin ribonuclease inhibitor (N211) and Taq DNA polymerase were from Promega (Madison WI, USA). The pcDNA $3 \cdot 1 / \mathrm{Zeo}(+)$ plasmid and Trizol were purchased from Invitrogen Co.

\section{Animals and cell culture}

Immature 19- to 21-day-old female Sprague-Dawley rats were purchased from Charles Rivers Laboratories (Barcelona, Spain). Housing conditions and experimental procedures were approved by the University of Las Palmas Committee on Animal Care that enforces European Union rule 86/609. Granulosa cells were obtained by follicle puncture from the ovaries of rats implanted with DES for 3 days and cultured in McCoy's 5 a medium (modified, without serum). R2C Leydig cells obtained from ATCC (Marassas, VA, USA) were grown and cultured in Waymouth MB752/1 medium supplemented with $20 \mathrm{mM}$ HEPES, $1.12 \mathrm{~g} / 1 \mathrm{NaHCO}_{3}, 15 \%$ horse serum and $50 \mu \mathrm{g} / \mathrm{ml}$ gentamycin.

\section{PCR and constructs}

Total RNA was extracted from duplicated cultures of granulosa and $\mathrm{R} 2 \mathrm{C}$ cells, using a modified guanidinium isothiocyanate method. The samples were stored frozen $\left(-70{ }^{\circ} \mathrm{C}\right)$ in diethylpyrocarbamate-treated water until use. After drying and optical density determination, reverse transcription was performed by standard protocols. Briefly, equal amounts of RNA $(1 \mu \mathrm{g})$ were incubated for $75 \mathrm{~min}$ at $42^{\circ} \mathrm{C}$ in $20 \mu \mathrm{l}$ (final volume) of $1 \times$ PCR buffer (10 $\mathrm{mM}$ Tris- $\mathrm{HCl}, 50 \mathrm{mM} \mathrm{KCl}, 5 \mathrm{mM} \mathrm{MgCl} 2$, and $0 \cdot 1 \%$ Triton X-100, $\mathrm{pH}$ 9), $500 \mathrm{ng}$ of polydeoxythymidine primers, $1 \mathrm{mM}$ dNTP, $5 \mathrm{U}$ AMV reverse transcriptase and $20 \mathrm{U}$ RNAsin ribonuclease inhibitor. Each cDNA was amplified using specific oligonucleotides designed to prime the different ICER isoforms in $25 \mu$ l of $1 \times$ PCR buffer containing (final concentrations) $2.5 \mu \mathrm{M}$ DIG-dUTP, 0.625 U Taq DNA polymerase and $125 \mathrm{ng}$ (10-15 pmol each) of the appropriate gene-specific synthetic primers. ICER primers were: ICER-5' ACTTA GGATCCACTGTGTACGGCCAAC; ICER-3' GTT AAATAGAATTCACTAATC TGTTTTGGG, the underlined sequences being restriction sites for BamHI in the $5^{\prime}$ primer and EcoRI in the $3^{\prime}$ primer that were introduced to facilitate the posterior subcloning. PCR products were detected by chemiluminescence and due to the high sensitivity of the method the thermal profile had to be adjusted as follows: $94^{\circ} \mathrm{C}$ for $1 \mathrm{~min}$ for denaturation, and $2 \mathrm{~min}$ at $62{ }^{\circ} \mathrm{C}$ and $72{ }^{\circ} \mathrm{C}$ for annealing and elongation 
respectively. Under these conditions unspecific background signals were reduced to undetectable levels and linearity was ensured for up to 29 cycles for ICER, and 17 cycles for G6PDH that was used as an internal amplification control. The amplified products were resolved by $1 \cdot 8 \%$ agarose gel electrophoresis and transferred to positively charged nylon membranes. Detection was performed with a commercially available DIG luminescent detection kit (Boehringer Mannheim, Barcelona, Spain) following the instructions of the manufacturer. The membranes were recorded and visualized in an imaging system with a cooled CCD capture system for chemiluminescence (Diana III from Raytest, Straubenhardt, Germany) using the software provided by the manufacturer (AIDA, 1D, 2D).

AROM-luc is $-161 \mathrm{bp}$ of the $5^{\prime}$ flanking sequence of the rat CYP19 promoter (Fitzpatrick \& Richards 1994) ligated to pGL2-Luc (Promega) and was donated by Dr J S Richards (Baylor College, Houston, TX, USA).

ICER sense (ICERs) and antisense (ICERas) expression vectors were constructed with cDNA obtained from forskolin-stimulated granulosa cells amplified with the Expand High Fidelity PCR System kit (Promega). In addition to the already described oligonucleotides, another set of primers was used where EcoRI in the forward and $\mathrm{BamHI}$ in the reverse primer were introduced to subclone ICER in the antisense orientation. A band corresponding to ICER-I was dissected out from the agarose gel and the DNA was isolated (using Quantum Prep Freeze and Squeeze DNA Gel Extraction Spin columns, Bio-Rad Laboratories, Richmond, CA, USA) and sequenced before the purified fragments were cloned into the pcDNA $3 \cdot 1 / \mathrm{Zeo}(+)$ plasmid (Invitrogen Co.) polylinker region to obtain pcDNA-ICER-Is and pcDNA-ICER-Ias constructs.

Transfections, establishment of ICER-expressing R2C clones and luciferase assays

Transient transfections were performed in $5 \times 10^{5}$ granulosa cells or $40 \%$ confluent R2C cells plated into $35 \mathrm{~mm}$ dishes. Plasmid DNA $(2.5 \mu \mathrm{g})$ in $100 \mu \mathrm{l}$ serum-free medium was mixed with $5 \mu \mathrm{l}$ lipofection reagent (Superfect, Qiagen Inc., Valencia, CA, USA), incubated for $10 \mathrm{~min}$ to form the transfection complex and added to PBS rinsed cells. After $4 \mathrm{~h}$ the DNA-lipid complexes were removed with PBS. Granulosa cells or R2C cells were thereafter reincubated in McCoy's $5 \mathrm{a}$ modified medium or $15 \%$ horse serum-supplemented Waymouth medium containing the appropriate treatments for the times indicated in each experiment.

To prepare stable R2C cell lines, $10 \mu \mathrm{g}$ plasmid DNA in $300 \mu \mathrm{l}$ serum-free Waymouth medium were transfected to R2C cells $\left(10^{5}\right)$. After thorough washing, reincubation for 3 weeks in Waymouth medium supplemented with a previously determined optimal dose $(400 \mu \mathrm{g} / \mathrm{ml})$ of Zeocin was performed to select the stably transfected clones. Media were changed every 3 days to eliminate cellular debris. The transfection produced similar numbers of clones, suggesting that ectopic expression of ICER was not toxic for the cells. About 100 clones of Zeocinresistent cells were pooled to obtain the stably transfected cell lines for each construct.

The luciferase activity in $20 \mu$ cellular extracts was assayed in an analytical luminescence detector (Luminova 1254-001, Bio-Orbit OY, Turku, Finland) for $10 \mathrm{~s}$ using the Luciferase Assay System kit (Promega) according to the manufacturer's protocol, and levels of luciferase activity were expressed as light units per $\mu \mathrm{g}$ protein.

\section{Electrophoretic mobility shift assays}

Nuclear cell extracts were prepared from forskolinstimulated granulosa cells (Andrews \& Faller 1991). Briefly, granulosa cells were scraped off the culture dishes into $1.5 \mathrm{ml}$ cold PBS, pelleted and resuspended in cold buffer A (10 mM HEPES-KOH pH 7.9, $1.5 \mathrm{mM} \mathrm{MgCl}_{2}$, $10 \mathrm{mM} \mathrm{KCl}, 0.5 \mathrm{mM}$ dithiothreitol, $0.2 \mathrm{mM}$ phenylmethylsulfonyl fluoride (PMSF)). The cells were kept on ice for $10 \mathrm{~min}$, vortexed and centrifuged before the supernatant fraction was discarded. The pellet was resuspended in cold buffer B (20 mM HEPES-KOH pH 7.9, $25 \%$ glycerol, $420 \mathrm{mM} \mathrm{NaCl}, 1.5 \mathrm{mM} \mathrm{MgCl}, 0.2 \mathrm{mM}$ EDTA, $0.5 \mathrm{mM}$ dithiothreitol, $0.2 \mathrm{mM}$ PMSF) and incubated on ice for $20 \mathrm{~min}$. Cellular debris was removed by centrifugation. The supernatants were stored at $-70{ }^{\circ} \mathrm{C}$ until use.

Nuclear proteins $(15-20 \mu \mathrm{g})$, were incubated for $20 \mathrm{~min}$ on ice in binding buffer (10 mM HEPES $\mathrm{pH} 7 \cdot 6$, $0.2 \mathrm{M} \mathrm{NaCl}, 5 \mathrm{mM} \mathrm{MgCl}, 0.5 \mathrm{mM}$ EDTA, $0.5 \mathrm{mM}$ EGTA, $5 \mu \mathrm{g} / \mathrm{ml}$ poly [dI-C] acid) and a 24-bp doublestranded oligonucleotide containing the CRE-like sequence of the rat $\mathrm{P} 450_{\mathrm{AROM}}$ promoter $(-161 /-138$ sequence) previously labeled with $\left[{ }^{32} \mathrm{P}-\gamma\right] \mathrm{ATP}$ by T4 polynucleotide kinase. Where indicated, increasing concentrations of the unlabeled probe, an AP-1 probe or a specific antibody to CREM-1 or CREB were added to the incubation mixture $30 \mathrm{~min}$ before the addition of the labeled DNA probe. After non-denaturing electrophoresis $(0.5 \times$ TBE, Tris-borate-EDTA) at $150 \mathrm{~V}$, the gels were dried and recorded as autoradiograms in a Molecular Dynamics 400A PhosphorImager.

\section{Statistical analysis}

Results are expressed as means \pm S.E.M., and significance was determined by analysis with Student's $t$-test for two group comparison or ANOVA for multiple group comparison. 


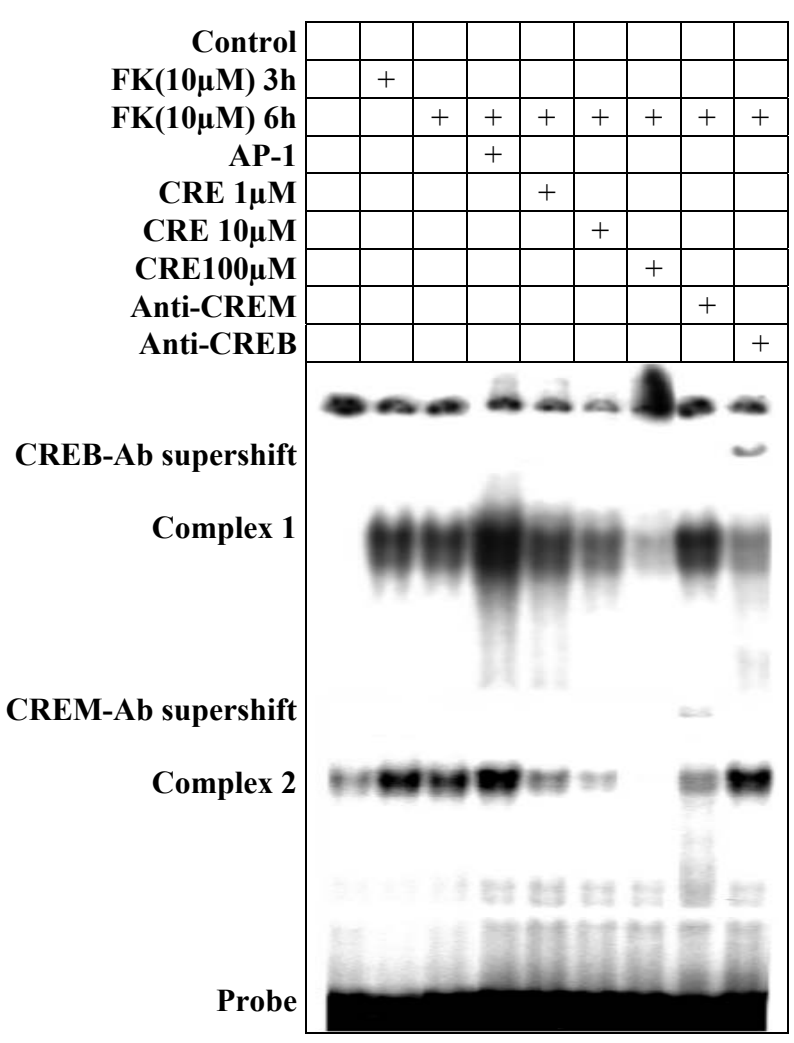

Figure 1 Mobility shift assay of protein extracts from forskolinstimulated granulosa cells. Nuclear extracts obtained from granulosa cells that were stimulated for 3 or $6 \mathrm{~h}$ with forskolin (FK; $10 \mu \mathrm{M}$ ) were incubated with a labeled oligonucleotide spanning the region of the CRE sequence of aromatase promoter. Pre-incubation with increasing concentrations of the unlabeled oligonucleotide, a consensus AP-1 oligonucleotide, CREM or CREB antibodies was performed where indicated. DNA-protein complexes were electrophoresed in non-denaturing conditions and visualized after recording as autoradiographs by photostimulable-storage imaging.

\section{Results}

\section{Mobility shift assay and transient overexpression of ICER in} granulosa cells

To determine if proteins synthesized in granulosa cells in response to cAMP analogs interact with the CRE in the ovarian aromatase promoter, a radiolabeled doublestranded oligonucleotide probe containing the CRE-like sequence (CLS) of $\mathrm{P} 450_{\mathrm{AROM}}$ promoter was incubated with protein extracts from granulosa cells treated for 3 and $6 \mathrm{~h}$ with forskolin. Figure 1 shows that proteins from forskolin-stimulated granulosa cells specifically bind the CLS sequence from CYP19 ovarian promoter as demonstrated by the fact that competition was achieved when incubations were performed with an excess of unlabeled P450 AROM promoter CRE, but not with an oligonucleotide containing the $\mathrm{AP}-1$ response sequence. In

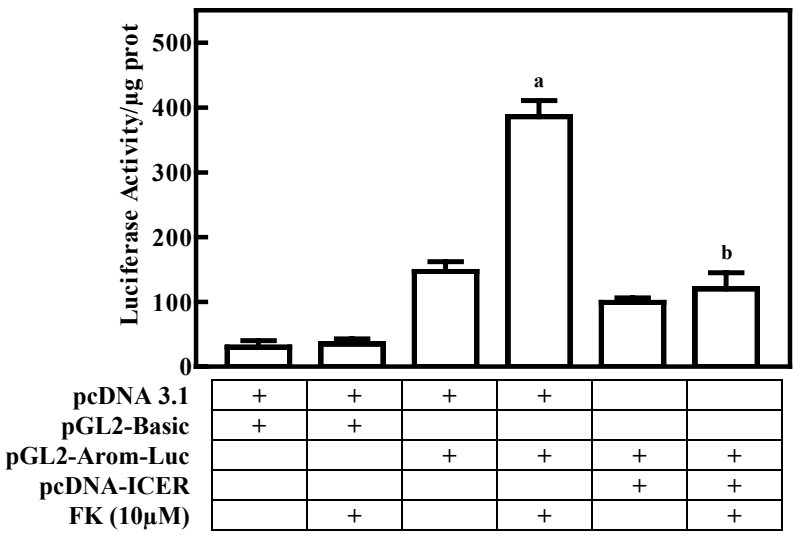

Figure 2 Activity of the $\mathrm{P} 450_{\text {AROM }}$ promoter in rat granulosa cells overexpressing ICER. pcDNA-ICERs was transiently cotransfected along with the pGL2-Arom-Luc plasmid into granulosa cells that were thereafter stimulated with forskolin (FK; $10 \mu \mathrm{M})$ for $6 \mathrm{~h}$, and luciferase activity was determined as described in the Materials and Methods section and represented as activity per $\mu$ g cellular protein. Data from triplicate measures of three different experiments were pooled and results are the means \pm S.E.M. a and b, $P<0.01$ compared with control unstimulated cells and with forskolin-treated ICER untransfected cells respectively.

agreement with previously reported data (Fitzpatrick \& Richards 1994, Michael et al. 1997) the slower mobility complex was supershifted after pre-incubation with an anti-CREB antibody, thus indicating that CREB is a component of the complex. A second, faster migrating protein-CLS complex was also detected. This complex most likely contains ICER since: (1) it was supershifted by an anti-CREM antibody; (2) consistent with the notion that proteins encoded by ICER are the smallest among the CREM isoforms as well as any other CRE-binding proteins, the complex has a very low molecular mass; (3) except for CREM- $\tau$ expressed in a specific and hormoneregulated fashion in the germ cells of the testis (Foulkes et al. 1992, 1993), no CREM isoforms other than ICER have been described to date as inducible.

The expression of $\mathrm{P} 450_{\mathrm{AROM}}$ promoter-driven reporter genes transiently transfected into granulosa cells can be induced by forskolin (Fitzpatrick \& Richards 1994). Therefore, to assess the effect of ICER on P450 AROM promoter activity the active $-161 \mathrm{bp} 5^{\prime}$ flanking sequence of the rat CYP19 promoter ligated to pGL2-Luc was transiently transfected into granulosa cells and the promoter activity in response to forskolin was measured when overexpression of ICER was simultaneously obtained by cotransfection with the pcDNA-ICER plasmid (Fig. 2). Luciferase activity was raised 2.5-fold in forskolin-stimulated cells $(P<0 \cdot 01)$. Cotransfection of the ICER construct completely prevented the forskolinincreased luciferase activity, thus providing support to the hypothesis that ICER can repress $\mathrm{P} 450_{\mathrm{AROM}}$ expression in rat granulosa cells. 


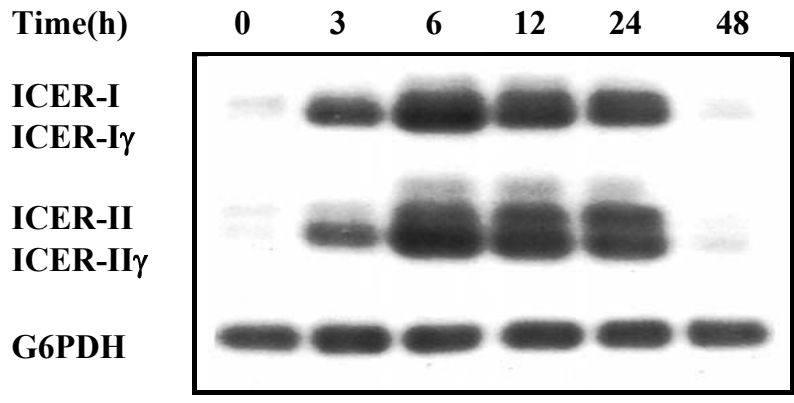

Figure 3 Effects of 8-Br-cAMP on ICER mRNA levels in R2C Leydig tumor cells. R2C cells were stimulated with 8-Br-cAMP $(1 \mathrm{mM})$ for the times indicated, and ICER mRNA levels were determined by RT-PCR as described in the Materials and Methods section. G6PDH was used as an internal amplification control.

ICER $m R N A$ levels in response to $A A M P$ and effects of the transient overexpression of ICER on P $450_{A R O M}$ promoter activity in R2C tumor Leydig cells

Early studies have shown that R2C tumor Leydig cells express high basal levels of aromatase mRNA but do not respond to the same levels of forskolin used in granulosa cells (Fitzpatrick \& Richards 1994). In these studies the transcriptional activation of a $\mathrm{P} 40_{\mathrm{AROM}}$ promoter reporter gene was assessed after $48 \mathrm{~h}$ stimulation with cAMP analogs, due to the fact that the full activity of the reporter gene is reached only $48 \mathrm{~h}$ after transfection. It seemed a reasonable possibility that a parallel cAMPinduced expression of ICER could account for the apparent unresponsiveness of $\mathrm{P} 450_{\mathrm{AROM}}$. To test this possibility, ICER mRNA levels were assessed by RTPCR in unstimulated and 8-Br-cAMP-activated cells. As shown in Fig. 3, basal levels of ICER were undetectable whereas the exposure to $8-\mathrm{Br}$-cAMP $(1 \mathrm{mM})$ resulted in a rapid induction of ICER mRNA with maximal induction of the four isoforms occurring after $6 \mathrm{~h}$ of 8 - $\mathrm{Br}$-cAMP stimulation. ICER mRNA levels remained high for up to $24 \mathrm{~h}$ and returned to the levels of unstimulated cells $48 \mathrm{~h}$ after 8-Br-cAMP treatment.

Thus it seemed likely that the length of stimulation routinely used would allow for ICER synthesis and P450 AR OM downregulation, resulting in the apparent lack of response to cAMP. To explore this hypothesis, the activity of luciferase as reporter gene of the P450 AROM promoter was measured in $\mathrm{R} 2 \mathrm{C}$ cells transiently transfected with the pGL2-Arom-Luc construct. R2C cells were stimulated with 8-Br-cAMP $(1 \mathrm{mM})$ for the usual $48 \mathrm{~h}$ and also 6, 12 and $24 \mathrm{~h}$ before the end of the 48-h experimental period. Figure 4 (open bars) shows that the stimulation of R2C Leydig tumor cells with 8-Br-cAMP for 6 and $12 \mathrm{~h}$ resulted in a twofold $(P<0 \cdot 01)$ increase in the luciferase activity. As in earlier reported data (Fitzpatrick \& Richards 1994), treatment with the cAMP analog for 24 and $48 \mathrm{~h}$ significantly $(P<0 \cdot 05)$ decreased the activity of the reporter gene below the levels of unstimulated cells. The use of this slightly different experimental approach has permitted the observation that in R2C cells P450 AROM activity can be stimulated with cAMP, the previously reported unresponsiveness being more likely attributable to ICER repression.

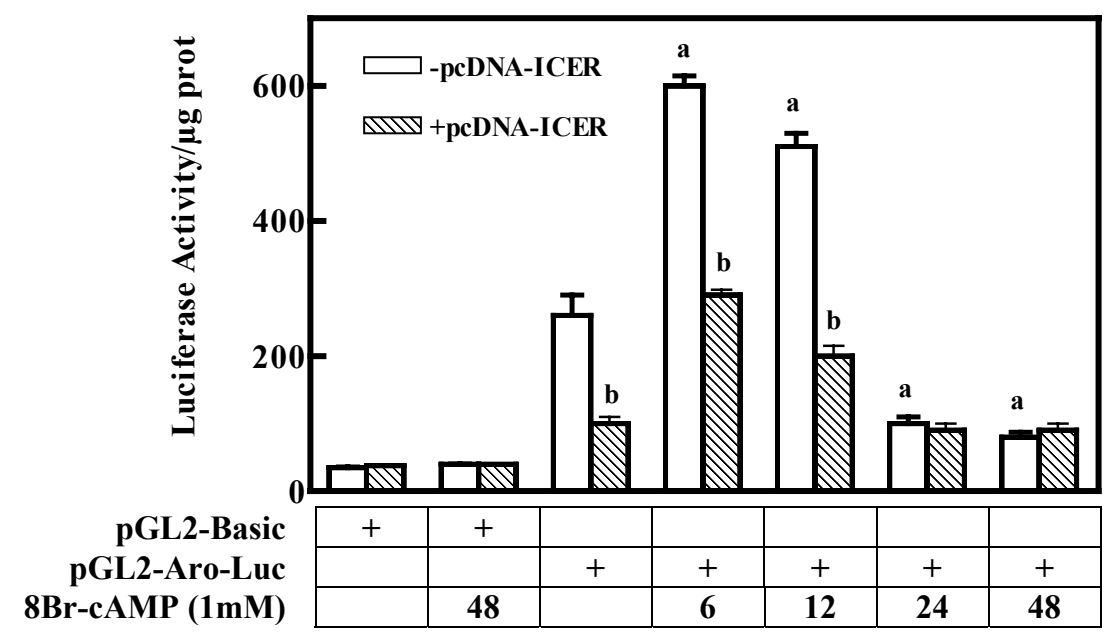

Figure 4 Activity of the $\mathrm{P} 450_{\text {AROM }}$ promoter in 8-Br-CAMP-stimulated R2C Leydig tumor cells and effects of the transient overexpression of ICER. R2C cells were transiently transfected with the pGL2-Arom-Luc construct (open bars) alone or with the pcDNA-ICERs (hatched bars) and treated with 8-Br-cAMP $(1 \mathrm{mM})$ for 6, 12, 24 and $48 \mathrm{~h}$ before the end of the experiment. Luciferase activity in the cellular extracts was assessed as described in the Materials and Methods section. Data from triplicate measures of three different experiments were pooled and the results are the means \pm S.E.M. $a$ and $b, P<0.01$ compared with control unstimulated cells and with ICER untransfected cells respectively. 
To support this latter assumption, we have also studied the effects of transiently cotransfecting the ICER expression vector on the basal and 8-Br-cAMP-stimulated activity of the AROM-luc construct. Figure 4 (hatched bars) shows that both basal and cAMP-stimulated activity of the luciferase reporter gene are significantly attenuated $(P<0 \cdot 01)$ when ICER is overexpressed, indicating that ICER can also repress aromatase expression in R2C cells.

\section{Effects of the stable expression of ICER sense and antisense constructs on $P 450_{A R O M}$ promoter-luciferase reporter expression in R2C tumor Leydig cells}

To strengthen the hypothesis of ICER being able to repress CYP19 transcription, we next compared the activity of the $\mathrm{P} 450_{\mathrm{AROM}}$ promoter luciferase construct in three polyclonal lines of $\mathrm{R} 2 \mathrm{C}$ tumor cells stably transfected with the pcDNA $3 \cdot 1 / \mathrm{Zeo}(+)$ empty vector or the pcDNA-ICER-Is or pcDNA-ICER-Ias. The results obtained with the pcDNA $3 \cdot 1 /$ Zeo cell line mimic those in wild-type cells. Figure 5 shows that the activity of the reporter gene increases 6 and $12 \mathrm{~h}$ after 8 -Br-cAMP and decreases after 24 and $48 \mathrm{~h}$ stimulation. ICER-Is overexpressing cells behaved as wild-type $\mathrm{R} 2 \mathrm{C}$ cells transiently transfected with the ICER expression vector, and did not respond to 8-Br-cAMP stimulation. Stimulation of ICER-Ias R2C cells with the cAMP analog resulted in greater activity of the reporter gene as compared with wild-type cells. Also, downregulation of the promoter activity in the ICER-Ias R2C cells after 24 and $48 \mathrm{~h}$ stimulation with 8-Br-cAMP was less pronounced than in pcDNA $3 \cdot 1 /$ Zeo transfected cells, thus further supporting the possibility that ICER is a repressor of CYP19 ovarian promoter.

\section{Discussion}

The transcription of ICER, the best characterized among the CREM repressor isoforms is induced by cAMP, and four CRE-like elements termed CAREs (cAMP autoregulatory elements) convey cAMP-responsiveness to the ICER promoter thus making it possible for ICER to autoregulate its own expression in a phosphorylation/ dephosphorylation independent fashion (Molina et al. 1993). These distinctive features provide the grounds for ICER to function as a regulator of the cyclic expression of cAMP-dependent genes (Lamas \& Sassone-Corsi 1997).

Cyclicity is a key functional property of many cells in the neuroendocrine, endocrine and reproductive systems. ICER has been reported to be involved in the repression of melatonin synthesis during the course of the normal circadian rhythm in the pineal gland (Stehle et al. 1993), to block adrenocorticotropin secretion from the corticotropes (Lamas et al. 1997), to function as a repressor of parathyroid hormone up-regulation of the vitamin D receptor in osteoblastic cells (Huening et al. 2002), and also participates in the long-term desensitization of the FSH and thyrotropin receptors (Lalli \& Sassone-Corsi 1995, Monaco et al. 1995).

Estrogen production by the ovary is also a cyclic process and despite the presence during the periovulatory surges of high levels of cAMP mobilizing hormones, the granulosa cells in the dominant preovulatory follicles are deprived of aromatase expression during luteinization (Hickey et al. 1990, Fitzpatrick et al. 1997).

The existence of a cycloheximide-sensitive factor involved in LH-dependent downregulation of CYP19 transcription was described in early studies on the regulation of aromatase expression (Fitzpatrick \& Richards 1991). Because LH/hCG-dependent increases in all the four isoforms of ICER mRNA have been reported (Mukherjee et al. 1998), we propose that proteins encoded by ICER may be this formally described cycloheximidesensitive factor and that induction of ICER expression by LH may be part of the molecular mechanism whereby aromatase is downregulated by this hormone. To support this role of ICER as a repressor of $\mathrm{P} 450_{\mathrm{AROM}}$ expression in the rat female gonad, we provide the following experimental observations: (1) the lower molecular mass complex of proteins from forskolin-stimulated granulosa cells specifically bound to the CRE of the ovarian aromatase promoter was supershifted by anti-CREM but not by anti-CREB antibody; (2) forskolin-induced luciferase activity was suppressed when the $\mathrm{P} 450_{\mathrm{AROM}}$ promoter-driven luciferase gene was transiently cotransfected with an ICER expression vector into granulosa cells or wild-type R2C cells, a Leydig tumor cell line routinely used for the study of $\mathrm{P} 450_{\mathrm{AROM}}$ promoter activity; (3) $\mathrm{P} 450$ AROM promoter activity in wild-type $\mathrm{R} 2 \mathrm{C}$ cells was elevated 6 and $12 \mathrm{~h}$ after stimulation with 8-Br-cAMP and downregulated to levels below basal activity 24 and $48 \mathrm{~h}$ after treatment. However, the promoter activity in response to the cAMP analog was completely attenuated in an $\mathrm{R} 2 \mathrm{C}$ polyclonal cell line overexpressing ICER, while another R2C line stably transfected with a construct of ICER in the antisense direction exhibited increases in the cAMP-inducible $\mathrm{P} 450_{\text {AROM }}$ promoter activity that were not downregulated to the same extent as in the wild-type cells.

Other, not necessarily mutually exclusive mechanisms, may help to explain LH downregulation of aromatase expression. In addition to the CRE-like sequence (Fitzpatrick \& Richards 1994, Michael et al. 1997) the ovarian promoter of CYP19 contains an hexameric steroidogenic factor-1 (SF-1) site downstream of the CRE-like sequence (Fitzpatrick \& Richards 1993, Young \& McPhaul 1998). The synthesis and phosphorylation of SF-1 and the increased levels of phosphorylated CREB appear to be equally necessary in order to obtain the optimal activation of hormone-dependent CYP19 transcription (Carlone \& Richards 1997). 


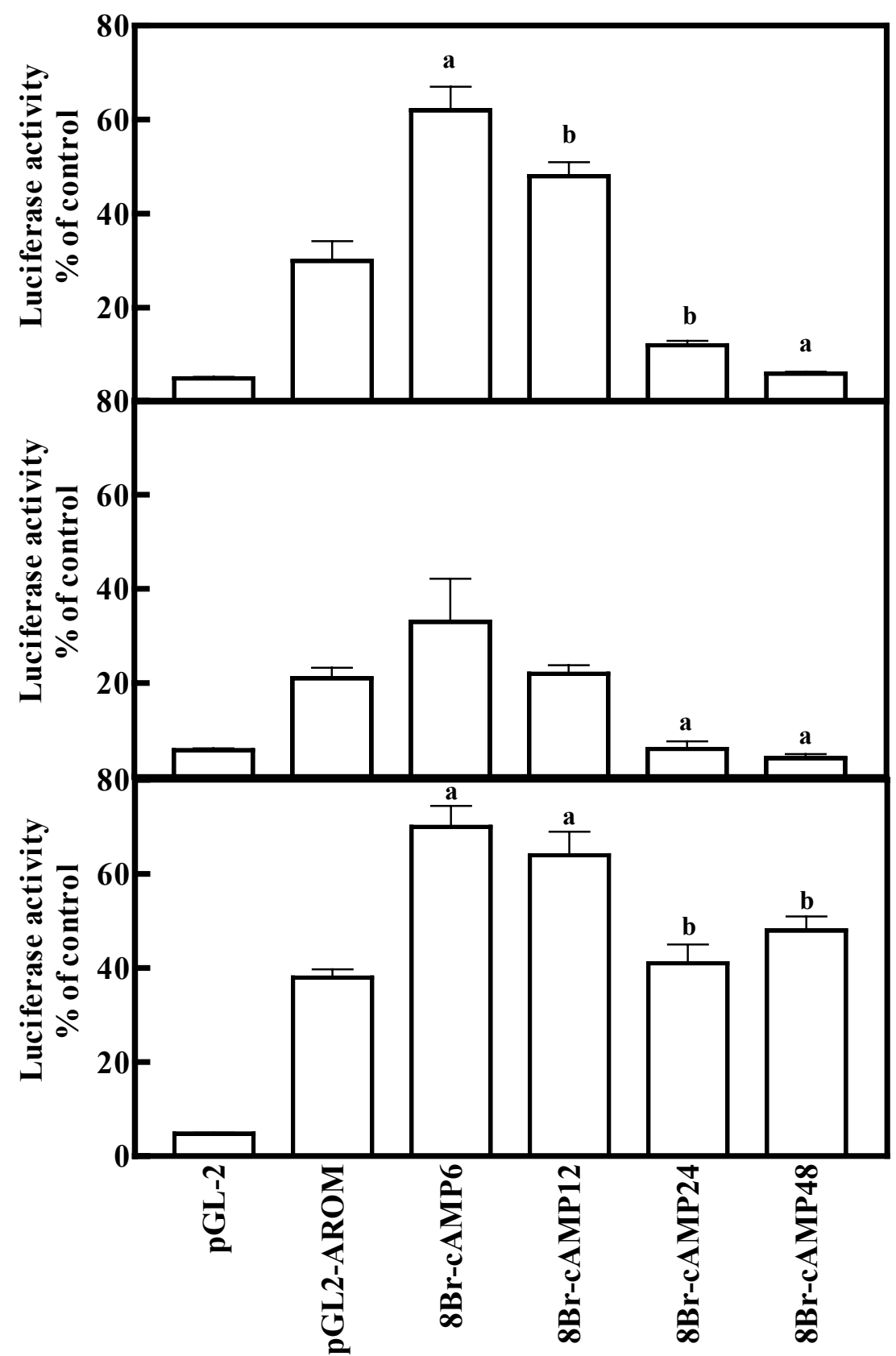

Figure 5 Functional activity of the $\mathrm{P} 450_{\mathrm{AROM}}$ promoter in wild-type and polyclonal lines of R2C Leydig tumor cells overexpressing ICER sense (s) or antisense (as). Wild-type (upper panel), ICERs (middle panel) or ICERas (lower panel) stably transfected R2C cells were transiently transfected with the pGL2-Arom-Luc construct. Luciferase activity was measured $48 \mathrm{~h}$ after the transfection in control or 8-Br-cAMP $(1 \mathrm{mM})$-stimulated cells that were treated for $6,12,24$ or $48 \mathrm{~h}(8 \mathrm{Br}-\mathrm{CAMP} 6,-12,-24,-48)$ before the end of the experiment as described in the Materials and Methods section. Data from triplicate measures of three different experiments were pooled and results are the means \pm S.E.M. $a, P<0 \cdot 01$ and b, $P<0 \cdot 05$ compared with control unstimulated cells. 
The preovulatory surge of LH almost completely abolishes SF-1 expression (Carlone \& Richards 1997). Therefore, inadequate levels of phosphorylated SF-1 together with ICER competition for CRE sites in the $\mathrm{P} 450$ AROM promoter may cooperate to repress aromatase expression in granulosa cells.

Finally, although extensively used to study $\mathrm{P} 450_{\mathrm{AROM}}$ promoter activity, the usefulness of $\mathrm{R} 2 \mathrm{C}$ cells has been greatly reduced due to their apparent unresponsiveness to hormonal stimulation. The interference of ICER in the assessment of CRE-dependent expression using CREmediated reporter genes has recently been documented in several cell lines (Kemp et al. 2002). We have shown here the existence of this experimental pitfall in R2C Leydig tumor cells, thus contributing to enlarge the possibilities of these cells as a potential model system to study not only basal but also hormone-induced expression of $\mathrm{P} 40_{\mathrm{AROM}}$.

\section{Funding}

This work was supported by the Direccion General de Enseñanza Superior e Investigación Científica Grants 98/0234 (to L F F) and 98/0233 (to C M R G).

\section{References}

Andrews NC \& Faller DV 1991 A rapid micropreparation technique for extraction of DNA-binding proteins from limiting number of mammalian cells. Nucleic Acids Research 192499.

Carlone DL \& Richards JAS 1997 Functional interactions, phosphorylation and levels of $3^{\prime}, 5^{\prime}$-cyclic adenosine monophosphateregulatory element binding protein and steroidogenic factor-1 mediate hormone-regulated and constitutive expression of aromatase in gonadal cells. Molecular Endocrinology 11 292-304.

Dwarki VJ, Montminy V \& Verma IM 1990 Both the basic region and the leucine zipper domain of the cyclic AMP response element binding (CREB) protein are essential for transcriptional activation. EMBO Journal $9225-232$.

Fitzpatrick SL \& Richards JS 1991 Regulation of cytochrome P450 aromatase messenger ribonucleic acid and activity by steroids and gonadotropins in rat granulosa cells. Endocrinology 129 1452-1462.

Fitzpatrick SL \& Richards JS 1993 Cis-acting elements of the rat aromatase promoter required for cyclic adenosine $3^{\prime}, 5^{\prime}$-monophosphate induction in ovarian granulosa cells and constitutive expression in R2C Leydig cells. Molecular Endocrinology 7 341-354.

Fitzpatrick SL \& Richards JS 1994 Identification of a cyclic adenosine $3^{\prime}, 5^{\prime}$-monophosphate-response element in the rat aromatase promoter that is required for transcriptional activation in rat granulosa cells and R2C Leydig cells. Molecular Endocrinology 8 1309-1319.

Fitzpatrick SL, Carlone DL, Robker RL \& Richards JS 1997 Expression of aromatase in the ovary: down-regulation of mRNA by the ovulatory luteinizing hormone surge. Steroids 62 197-206.

Foulkes NS \& Sassone-Corsi P 1992 More is better: activators and repressors from the same gene. Cell 68 411-414.

Foulkes NS, Borrelli E \& Sassone-Corsi P 1991 CREM gene: use of alternative DNA-binding domains generate multiple antagonists of cAMP-transcription. Cell 64 739-749.

Foulkes NS, Mellström B, Benusiglio E \& Sassone-Corsi P 1992 Developmental switch of CREM function during spermatogenesis: from antagonist to activator. Nature $35580-84$.
Foulkes NS, Schlotter F, Pevet P \& Sassone-Corsi P 1993 Pituitary hormone FSH directs the CREM functional switch during spermatogenesis. Nature 362 264-267.

Gonzalez GA, Yamamoto KK, Fisher WH, Karr D, Menzel P, Biggs WH, Vale WW \& Montminy MR 1989 A cluster of phosphorylation sites on the cyclic AMP-regulated nuclear factor CREB predicted by its sequence. Nature 23 749-752.

Hai TW, Liu F, Coukos WC \& Green NR 1989 Transcription factor ATF cDNA clones: an extensive family of leucine zipper proteins able to selectively form DNA-binding heterodimers. Genes and Development 3 2083-2090.

Heckert LL, Daley IJ \& Griswold MD 1992 Structural organization of the follicle-stimulating hormone receptor gene. Molecular Endocrinology 6 70-80.

Hickey GJ, Krasnow JS, Beattie WG \& Richards JAS 1990 Aromatase cytochrome P450 in rat ovarian granulosa cells before and after luteinization: adenosine $3^{\prime}, 5^{\prime}$-monophosphate-dependent and -independent regulation. Cloning and sequencing of rat aromatase cDNA and 5' genomic DNA. Molecular Endocrinology 4 3-12.

Hsueh AJ, Adashi EY, Jones PB \& Welsh TH Jr 1984 Hormonal regulation of the differentiation of cultured granulosa cells. Endocrine Reviews 5 72-127.

Huening M, Yehia G, Molina CA \& Christakos S 2002 Evidence for a regulatory role of inducible cAMP early repressor in protein kinase A-mediated enhancement of vitamin D receptor expression and hormone modulation. Molecular Endocrinology 16 2052-2064.

Kellis JT Jr \& Vickery LE 1987 The active site of aromatase cytochrome P450. Journal of Biological Chemistry 262 8840-8844.

Kemp DM, George SE, Kent TC, Bungay PJ \& Naylor LH 2002 The effect of ICER on screening methods involving CRE-mediated reporter gene expression. Journal of Biomolecular Screening 7 141-148.

Lalli E \& Sassone-Corsi P 1995 Thyroid-stimulating hormone (TSH)directed induction of the CREM gene in the thyroid gland participates in the long-term desensitization of the TSH receptor. PNAS 92 9633-9637.

Lamas M \& Sassone-Corsi P 1997 The dynamics of the transcriptional response to cyclic adenosine $3^{\prime}, 5^{\prime}$-monophosphate: recurrent inductibility and refractory phase. Molecular Endocrinology 11 1415-1424.

Lamas M, Molina C, Foulkes NS, Jansen E \& Sassone-Corsi P 1997 Ectopic expression in pituitary corticotroph AtT20 cells: effects on morphology, cell cycle and hormonal production. Molecular Endocrinology 11 1425-1434.

Laoide BM, Foulkes NS, Schlotter F \& Sassone-Corsi P 1993 The functional versatility of CREM is determined by its modular structure. EMBO Journal 12 1179-1191.

McNatty KP, Smith DM, Makris A, Osanthanondh R \& Ryan KJ 1979 The microenvironment of the human antral follicle: interrelationships among the steroid levels in antral fluid, the population of granulosa cells and the status of the oocyte in vivo and in vitro. Journal of Clinical Endocrinology and Metabolism 49 851-860.

Means GD, Kilgore MW, Mahendroo MS, Mendelson CR \& Simpson ER 1991 Tissue-specific promoters regulate aromatase cytochrome P450 gene expression in human ovary and fetal tissues. Molecular Endocrinology 5 2005-2013.

Michael MD, Michael LF \& Simpson ER 1997 A CRE-like sequence that binds CREB and contributes to CAMP-dependent regulation of the proximal promoter of the human aromatase P450 (CYP19) gene. Molecular and Cellular Endocrinology 15 147-156.

Molina CA, Foulkes NS, Lalli E \& Sassone-Corsi P 1993 Inductibility and negative autoregulation of CREM: an alternative promoter directs the expression of ICER, an early response repressor. Cell $\mathbf{7 5}$ 875-886.

Monaco L, Foulkes NS \& Sassone-Corsi P 1995 Pituitary folliclestimulating hormone (FSH) induces CREM gene expression in Sertoli cells: involvement in long term desensitization of the FSH receptor. PNAS 92 10673-10677. 
Mukherjee A, Park-Sarge O-K \& Mayo KE 1996 Gonadotropins induce rapid phosphorylation of the $3^{\prime}, 5^{\prime}$-cyclic adenosine monophosphate response element binding protein in ovarian granulosa cells. Endocrinology 137 3234-3245.

Mukherjee A, Urban J, Sassone-Corsi P \& Mayo KE 1998 Gonadotropins regulate inducible cyclic adenosine $3^{\prime}, 5^{\prime}$-monophosphate early repressor in the rat ovary: implications for inhibin $\alpha$ subunit gene expression. Molecular Endocrinology 12 785-800.

Nelson DR, Kamataki T, Waxman DJ, Guengerich FP, Estabrook RW, Feyereisen R, Gonzalez FJ, Coon MJ, Gunsalus IC, Gotoh O, Okuda K \& Nebert DW 1993 The P450 superfamily: update on new sequences, gene mapping, accession numbers, early trivial names of enzymes, and nomenclature. DNA Cell Biology 12 1-51.

Pei L, Dodson R, Schoderbeck WE, Maurer RA \& Mayo KE 1991 Regulation of the alpha inhibin gene by cyclic adenosine $3^{\prime}, 5^{\prime}$-monophosphate after transfection into rat granulosa cells. Molecular Endocrinology 5 521-534.

Shaywitz AJ \& Greenberg ME 1999 CREB: a stimulus-induced transcription factor activated by a diverse array of extracellular signals. Annual Review of Biochemistry 68 821-861.

Simpson ER Mahendroo MS, Means GD, Kilgore MW, Hinshelwood MM, Graham-Lorence S, Amarneh B, Ito Y, Fisher CR, Michael MD, Mendelson CR \& Bulun SE 1994 Aromatase cytochrome P450, the enzyme responsible for estrogen biosynthesis. Endocrine Reviews 15 242-355.

Simpson ER, Michael MD, Agarwal VR, Hinshelwood MM, Bulun SE \& Zhao Y 1997a Expression of the CYP19 (aromatase) gene: an unusual case of alternative promoter usage. FASEB Journal 11 29-36.
Simpson ER, Zha Y, Agarwal VR, Michael MD, Bulun SE, Hinshelwood MM, Graham-Lorence S, Sun T, Fisher CR, Qin K \& Mendelson CR $1997 b$ Aromatase expression in health and disease. Recent Progress in Hormone Research 52 185-214.

Stehle JH, Foulkes NS, Molina CA, Simonneaux V, Pevet P \& Sassone-Corsi P 1993 Adrenergic signals direct rhythmic expression of transcriptional repressor CREM in the pineal gland. Nature 365 314-320.

Tsai-Morris CH, Buczko E, Wang W, Xie XZ \& Dufau ML 1991 Structural organization of the rat luteinizing hormone (LH) receptor gene. Journal of Biological Chemistry 266 11355-11359.

Turner IM, Saunders PT, Shimasaki S \& Hillier SG 1989 Regulation of inhibin subunit gene expression by FSH and estradiol in cultured rat granulosa cells. Endocrinology 125 2790-2792.

Young M \& McPhaul MJ 1998 A steroidogenic factor-1-binding site and cyclic $3^{\prime}, 5^{\prime}$-monophosphate response element-like elements are required for the activity of the rat aromatase promoter in rat Leydig tumor cell lines. Endocrinology 139 5082-5093.

Yun YD, Dumolin M \& Habener JF 1990 DNA binding and dimerization domains of adenosine $3^{\prime}, 5^{\prime}$-cyclic monophosphateresponsive protein $\mathrm{CREB}$ reside in the carboxy terminal 66 amino acids. Molecular Endocrinology 4 931-939.

Received 30 July 2003

Accepted 20 August 2003

Made available online as an

Accepted Preprint 26 August 2003 